Jurnal Kesehatan Perintis (Perintis's Health Journal) 8 (1) 2021: 17-25

Contents list available at JKP website

Jurnal Kesehatan Perintis (Perintis's Health Journal)

Journal homepage: https://jurnal.stikesperintis.ac.id/index.php/JKP

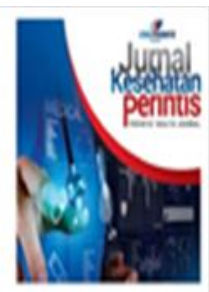

Literature Review

\title{
Akar Mimosa Pudica L yang Diozonasi Terhadap Penyembuhan Luka Ulkus Diabetikum
}

\section{Eli Ermawati ${ }^{*}$, Niken Safitri Dyan Kusumaningrum ${ }^{1}$, Anita Aprilia Yunita Sari ${ }^{1}$, Musdhalifah Hesti Anggraini ${ }^{2}$,Vida Dwi Pringgani ${ }^{1}$}

${ }^{1}$ Departemen IImu Keperawatan, Universitas Diponegoro, Semarang,Indonesia

${ }^{2}$ Departemen Fisika, Universitas Diponegoro, Semarang, Indonesia

Article Information :

Submission: Jun 14, 2021; Revised: Jun 25, 2021; Accepted:Jun 29, 2021; Available online: Jun 30,2021

*Corresponding author : eliermawati@student.undip.ac.id

\begin{abstract}
ABSTRAK
Diabetes mellitus adalahpenyakit tidak menular termasuk salah satu penyebab kejadian mortalitas di dunia, termasuk di Indonesia. Prevalensi diabetes di Indonesia berdasarkan data semakin meningkat dalam setiap tahunnya. Salah satu komplikasi yang paling mengancam adalah ulkus diabetikum. Selama beberapa dekade terakhir, perkembangan teknologi plasma medis menggunakan ozon sebagai agen yang membantu penyembuhan luka. Aplikasi dan riset Mimosa pudica L.sebagai wound healing. Tujuan dari review narrative ini untuk mengetahui potensi ekstrak Mimosa pudica $L$ dengan ozonasi sebagai terapi topikal untuk meningkat penyembuhan ulkus diabetikum. Pencarian literatur menggunakan database Science direct, PubMed, Ebsco, Scopus dan ProQuest dengan kriteria inklusi yang ditentukan. Hasil dari studi literatur bahwa kandungan senyawa kimia pada ekstrak akar Mimosa pudica $L$. telah terbukti memiliki aktivitas penyembuhan luka dan aktivitas antidiabetik. Pemanfaatan ozonasi sebagai agen antibakteri dengan menggunakan alat degenerator ozon untuk mengubah gas ozon menjadi cair ke dalam suatu ekstrak menggunakan parameter tertentu dapat mendukung wound healing. Sehingga perpaduan ekstrak akar Mimosa pudica L. dengan proses ozonasi memiliki potensi untuk dikembangkan dalam menunjang penyembuhan ulkus diabetikum agar lebih efektif dan efisien.
\end{abstract}

Kata Kunci: akar Mimosa pudica L., ozonasi, ulkus diabetikum, wound healing

\section{ABSTRACT}

Diabetes mellitus is a non-communicable disease which is one of the causes of mortality in the world, including in Indonesia. The prevalence of diabetes in Indonesia is increasing every year. One of the most threatening complications is diabetic ulcer. Over the last few decades, there have been developments in medical plasma technology using ozone as a wound healing agent. Mimosa pudica $L$. root extract has been widely studied. The purpose of this narrative review is to determine the potential of Mimosa pudica $L$ extract with 
ozonation as a topical therapy to improve diabetic ulcer healing. Literature search using the database Science direct, PubMed, Ebsco, Scopus and ProQuest with specified inclusion criteria. The results of the narrative review show that the chemical compounds in Mimosa pudica $L$. root extract have been shown to have wound healing and antidiabetic activity. The use of ozonation as an antibacterial agent by using an ozone degenerator to convert ozone gas to liquid into an extract using certain parameters has been shown to support wound healing. So that the combination of Mimosa pudica L. root extract with the ozonation process has the potential to be developed in supporting the healing of diabetic ulcers to make it more effective and efficient.

\section{Keywords: root Mimosa pudica L., ozonized, diabetic ulcer, wound healing}

\section{PENDAHULUAN}

Diabetes Mellitus (DM) adalah penyakit tidak menular yang termasuk salah satu penyebab kejadian mortalitas di dunia, termasuk di Indonesia. Prevalensi diabetes di Indonesia berdasarkan data semakin meningkat dalam setiap tahunnya. Menurut laporan World Health Organization (2014) data penderita diabetes di dunia menunjukkan 422 juta, $8,5 \%$ dari total penduduk dunia. International Diabetic Federation (IDF) tahun 2017 menyampaikan bahwa penyakit diabetes di Indonesia menduduki peringkat keenam di dunia yaitu dengan jumlah penderita diabetes pada usia 20-79 tahun berjumlah sekitar 10,3 juta jiwa. Prevalensi diabetes mellitus di Indonesia memperlihatkan peningkatan yang cukup tinggi, yaitu pada tahun 2013 sejumlah $6,9 \%$ menjadi $8,5 \%$ pada tahun 2018 (Riskesdas, 2018).

Penyakit diabetes mellitus yang sudah parah, akan menyebabkan komplikasi dibeberapa organ, salah satunya di organ ekstremitas seperti ulkus diabetikum (Nasiri et all, 2015). Ulkus diabetikum adalah luka terbuka pada kulit yang meluas hingga ke dermis dan biasanya terjadi di kaki, yang biasa disebut Diabetic Foot Ulcer (DFU). IDF memperkirakan pada tahun 2030 penderita diabetes mencapai 366 juta orang, dengan $15 \%$ diantaranya berisiko menderita ulkus diabetikum. Ulkus diabetikum yang tidak mendapatkan penanganan dengan baik semakin lama akan menyebabkan terjadinya infeksi, ulkus dapat berkembang menjadi gangren maka jaringan akan nekrosis, sehingga meningkatkan kemungkinan amputasi. Perawatan ulkus diabetikum membutuhkan biaya yang tinggi, di Amerika Serikat biaya perawatan berkisar US\$8.000 sampai US $\$$
17.000 tergantung kelas dan tingkat keparahannya (Jeffcoate et al., 2018).

Salah satu treatmen atau cara untuk meminimalkan meluasnya infeksi adalah dengan teknik perawatan dan pembersihan luka (Volmer-Thole dan Lobmann, 2016). perkembangnya teknologi, dilakukan banyak inovasi penelitian yang berfokus tentang wound healing pada penderita ulkus diabetikum. Salah satunya menggunakan topical therapy dalam modern dressing, metode ini sangat baik digunakan untuk menjaga serta mempertahankan kelembapan luka, dan mminimalisiti populasi bakteri di area luka. Beberapa jenis hidrogel dan salep yang digunakan sebagai topikal terapi telah tebukti mampu memberikan efek penyembuhan pada luka pasien DM (Wijonarko, 2016).

Seiring meningkatnya penderita ulkus diabetikum di Indonesia sehingga membutuhkan biaya yang mahal untuk pengobatan. Itu sebabnya dibutuhkan alternatif terapi, dengan menggunakan obat-obatan alternatif. Proses perkembangan obat tradisional sudah pesat, dikarenakan efek samping yang dihasilkan relatif kecil dan mampu mendapatkan hasil yang lebih efektif dan ekonomis. Pada tanaman juga mempunyai potensi kandungan senyawa yang bisa digunakan untuk wound healing. Salah satunya tanaman Mimosa pudica $L$. yang dikenal dengan istilah putri malu banyak tumbuh dan berkembang di Indonesia yang beriklim tropis. Selain itu, putri malu dapat dengan mudah dijumpai karena dapat tumbuh liar di jalanan, pinggir jalan, lapangan, dan tempat terbuka yang terpapar sinar matahari dan dapat tumbuh di ketinggian hingga 1000 mdpl (Uluputty, 2014). 
Akar tanaman Mimosa pudica $L$. mengandung beberapa komponen kimia, seperti tannin, saponin, steroids, flavonoids, glycosides, non-protein amino acid leucenine (mimosine), alkaloids (Libon et al., 2018). Sedangkan untuk pemanfaatan secara farmakologi dapat digunakan untuk antiviral, aphrodisiac, antimicrobial, antivenom, antihepatotoxic, antioksidan, diuretik dan wound healing (Onyije et al, 2018). Proses antimikroba bisa ditambahkan melalui proses ozonasi. Selama beberapa dekade terakhir, ozon yang dihasilkan menggunakan teknologi medis plasma telah diteliti sebagai agen yang membantu penyembuhan luka. Proses terapi ozon yang digunakan untuk penyembuhan luka pada umumnya diberikan sebgai topical terapi sebagai antimikroba. Zat ozon dapat larut dalam air atau plasma ataupun dalam serum salin fisiologis dan juga dapat menghasilkan (radical oxygen species). Kisaran therapeutic window adalah $20-80 \mathrm{ug} / \mathrm{mg}$ ozon per gram darah (Volmer-Thole dan Lobmann, 2016).

Berdasarkan fakta-fakta diatas, penulis meninjau kajian literature bertujuan untuk memberikan sebuah gambaran tentang potensi ekstrak akar Mimosa pudica $L$. yang memiliki aktivitas wound healing dan antidiabes. Selanjutnya membahas potensi ozonasi sebagai antimikroba yang mendukung proses wound healing pada ulkus diabetikum.

\section{METODE}

Metode yang digunakan adalah literarture review. Proses pencarian literature dilakukan pada bulan Agustus September 2020. Data artikel jurnal yang digunakan merupakan data sekunder yang didapat berupa artikel bereputasi baik nasional maupun internasional dengan topik yang sudah ditentukan. Pencarian literature menggunakan lima database dengan menggunakan kriteria kualitas tinggi dan sedang, yaitu Scopus, ProQuest, Pubmed, Ebsco dan Science Direct, dengan artikel diatas 2010. Proses pencarian jurnal atau artikel dengan menggunakan keyword "root Mimosa pudica L., ozonized, diabetic ulcer, wound healing" dan menggunakan Boolean operator (AND, OR NOT or AND NOT) berfungsi agar dapat memperluas atau menspesifikkan pencarian. Hasil pencarian diperiksa duplikasi, ditemukan artikel yang sama sehingga tersisa 305 artikel. Peneliti melakukan skrining berdasarkan judul $(\mathrm{n}=$ 107), abstrak $(n=52)$ dan full text $(n=23)$. Hasil seleksi artikel studi dapat digambarkan dalam diagram 1.

Research identified through database

Scopus, ProQuest, Pubmed, Ebsco and Science Direct $(n=508)$

Record after duplicates removed $(n=305)$

Titles identified and screened $(n=107)$

Abstract and screened $(n=52)$

Full copies retrieved and assessed for eligibility $(n=23)$

\section{Diagram 1. Flow Narrative Review Berdasarkan PRISMA 2009 (Polit and Beck, 2013)}

\section{PEMBAHASAN \\ Ulkus Diabetikum}

Ulkus diabetikum merupakan salah satu komplikasi mayor diabetes yang sering dialami oleh penderita diabetes mellitus. Ulkus diabetikum didefinisikan sebagai keadaan ditemukannya lesi pada jaringan yang dapat berkembang menjadi gangren sehingga terjadi nekrosis diarea pergelangan kaki serta berhubungan dengan gangguan neurologis dan penyakit pembuluh darah perifer yang disebabkan oleh beberapa faktor (Younis et al., 2018). Ulkus diabetikum disebabkan oleh kombinasi beberapa faktor risiko, termasuk neuropati, penyakit oklusi arteri perifer, dan ulserasi jaringan (Volmer-Thole dan Lobmann, 2016).

Ada dua faktor utama berupa faktor risiko dan faktor predisposisi dari DFU yaitu neuropati dan angiopati yang terjadi secara bersamaan dengan deformitas kaki atau 
trauma secara mekanik, kimiawi, atau termal yang menyebabkan hilangnya integritas kulit. Faktor pemberat lainnya seperti iskemia, kekebalan abnormal yang mendukung perkembangan infeksi DFU (Jeffcoate et al., 2018). Studi sebelumnya menyampaikan bahwa faktor risiko ulkus diabetikum dan faktorterkait terdiri dari dislipidemia, riwayat amputasi sebelumnya, diabetes neuropati, pembentukan kalus di kaki, durasi diabetes, Ankle Brachial Index (ABI), tingkat pengetahuan, dan Body Mass Index (BMI) (Bortoletto et al., 2014). Kondisi ulkus diabetikum yang kronik dengan penanganan kurang tepat akan menyebabkan penurunan kualitas hidup penderita ulkus diabetikum (Sari et al., 2018).

\section{Proses Wound Healing pada Ulkus Diabetikum}

Penatalaksanaan ulkus diabetikum memerlukan pendekatan holistik, dengan mempertimbangkan kondisi sistemik, komplikasi neuropati atau aterosklerosis, dan klasifikasi cedera. Penyembuhan luka terjadi mekanisme proses koagulasi dan inflamasi, yang mencegah kehilangan darah, peradangan dan debridemen luka, perbaikan, termasuk proliferasi sel, dan jaringan renovasi dan deposisi kolagen (Jeffcoate et al., 2018). Penyembuhan luka ulkus diabetikum melibatkan sel-sel dan sel-matriks yang terus menerus berinteraksi dan berlanjut dalam tiga fase yaitu inflamasi, proliferasi, dan renovasi sel. Sedangkan proses perawatan ulkus diabetikum terdiri dari tiga tahap, yaitu pembersihan (pencucian), debridemen, dan balutan luka (Desalu et al., 2011)

Debridemen merupakan pengangkatan biofilm bakteri dan jaringan nekrotik dari luka ulkus untuk mencegah infeksi. Debridemen dan pembersihan luka dilakukan setiap tujuh hingga empat belas hari dengan bantuan antibiotik dan larutan garam isotonik (NaCL 0,9\%) (Karri et al., 2016). Fase satu adalah fase koagulasi dan inflamasi (0-3 hari) dan ini melibatkan migrasi neutrofil pada margin sayatan, bergerak menuju bekuan fibrin. Fase dua adalah fase proliferasi (3-12 hari) di mana sebagian besar neutrofil digantikan oleh makrofag. Granulasi jaringan secara progresif menginvasi ruang sayatan dan sayatan ruang diisi dengan jaringan granulasi. Fibrin kolagen menjadi lebih banyak berlimpah dan mulai menjembatani sayatan. Fase tiga adalah fase renovasi (36 bulan), yang melibatkan akumulasi kolagen dan proliferasi fibroblas secara terus-menerus yang ditandai dengan penurunan infiltrasi leukosit dan edema. Fase ini melibatkan sintesis serat kolagen, yang menyebabkan peningkatan daya tarik kekuatan kulit (Cotran et al.,2017).

Prinsip dasar dalam proses penyembuhan luka secara optimal adalah dengan meminimalkan terjadiya kerusakan jaringan dan dengan memberikan perfusi jaringan serta oksigenasi yang memadai, begitupula nutrisi yang tepat dan lingkungan luka yang dipertahankan lembab berfungsi untuk proses pegembalian kesinambungan anatomi dan fungsi yang terpengaruh bagian (Karri et al., 2016). Penggunaan dari proses topical therapy berfungsi untuk menjaga kelembapan pada luka dan juga meminimalkan populasi bakteri di area luka. Beberapa jenis hidrogel dan salep sebagai proses topical therapy telah tebukti mampu memberikan efek penyembuhan pada luka pasien DM. Pemilihan topical therapy adalah untuk menciptakan suatu kondisi lingkungan fisiologis untuk proses penyembuhan luka. Hal-hal yang harus dipertimbangkan dalam menentukan media topical therapy diantaranya mencegah dan mengatasi infeksi, membersihkan luka, mengangkat jaringan nekrotik, mempertahankan kelembapan, mengisi rongga kosong, mengontrol bau, meminimalkan nyeri, dan melindungi kulit sekitar luka (Wijonarko, 2016).

\section{Aktivitas Wound Healing Ekstrak Akar Mimosa pudica $L$}

Mimosa pudica $L$. dalam bahasa Indonesia adalah putri malu adalah tanaman perdu pendek yang tergolong gulma anggota suku polong-polongan yang mudah dikenal karena daun-daunnya yang dapat secara cepat menutup dengan sendirinya saat disentuh (Kokane et al., 2009). Tumbuhan Mimosa pudica $L$. termasuk dalam genus Mimosaideae banyak diteliti baik di dalam maupun luar negeri serta sudah lama dipakai dalam pengobatan sebagai antiinfeksi saluran 
pernapasan, herpes, infeksi kulit, diare, asma, pembengkakan karena luka, bahkan insomnia (Libon et al., 2018).

Pemanfaatan secara farmakologi, dapat digunakan untuk antiviral, aphrodisiac, antimicrobial, anti-venom, antihepatotoxic, antioxidant, diuretik dan wound healing (Jose $\mathrm{J}$ et al, 2014). Kandungan senyawa kimia pada putri malu yaitu mimosis, tannin, flavanoid, steroid/terpenoid dan sterol (Onyije et al., 2018). Di negara-negara Asia Tenggara telah diguakan sebagai agen antidiabetes, antibakteri, penyembuhan luka, antidiabetik, antivenom dan memiliki potensi antikanker (Tunna et al, 2014). Studi lain menyebutkan Mimosa pudica $L$. memiliki kandungan alkaloid, steroid, tanin, triterpen, flavonoid, glikosida, kuinin, fenol, saponin, kumarin, c-glikosilflavon. Dalam senyawa flavonoid terdapat antioksidan natural bernama quercetin yang mempunyai fungsi seperti menurunkan kadar glukosa darah (BGL), melindungi pankreas dari oxidative stress (Kumar and Pandey, 2013). Peneliti telah melakukan pencarian literatur tentang potensi wound healing dari ekstrak akar Mimosa pudica $L$ tabel 1 menunjukkan aktivitas wound healing ekstrak Mimosa pudica $L$.

Tabel 1. aktivitas wound healing ekstrak Mimosa pudica $L$.

\begin{tabular}{|c|c|c|c|c|c|}
\hline No & Model Luka & $\begin{array}{c}\text { Kandungan } \\
\text { Senyawa } \\
\text { Ekstrak }\end{array}$ & & Efek Penyembuhan Luka & Referensi \\
\hline 1 & $\begin{array}{l}\text { Luka eksisi insisi, } \\
\text { dan estimasi } \\
\text { parameter biokimia }\end{array}$ & $\begin{array}{l}\text { Metanol dan } \\
\text { fenol }\end{array}$ & & $\begin{array}{l}\text { Meningkatkan prolifesai } \\
\text { seluler. } \\
\text { Meningkatkan daya tarik } \\
\text { menarik kolagen luka pada } \\
\text { kulit. } \\
\text { Meningkatkan biomarker } \\
\text { hydroxyproline } \\
\text { 20 }\end{array}$ & $\begin{array}{c}\text { Kokane, et } \\
\text { al.(2009) }\end{array}$ \\
\hline 2 & Luka sayatan & Etanol & - & $\begin{array}{l}\text { Aktifitas antiinflamasi dengan } \\
\text { menghambat peningkatan } \\
\text { jumlah fibroblas dan sintesis } \\
\text { kolagen mukopolisakarida } \\
\text { selama pembentukan } \\
\text { jaringan granuloma. } \\
\text { Kandungan fenol sebagai } \\
\text { aktifitas antioksidan dengan } \\
\text { membersihkan radikal } \\
\text { bebas. }^{21}\end{array}$ & $\begin{array}{l}\text { Azam, et } \\
\text { al. (2015) }\end{array}$ \\
\hline 3 & Luka eksisi & Polifenol & - & $\begin{array}{l}\text { Meningkatkan epitelisasi, } \\
\text { sintesis kolagen, dan } \\
\text { terutama regenerasi kulit } \\
\text { Meningkatkan angiogenesis } \\
\text { dan stabilisasi pembuluh } \\
\text { darah, serta mempercepat } \\
\text { pembentukan jaringan } \\
\text { granulasi. }\end{array}$ & $\begin{array}{c}\text { Choi, et al. } \\
(2018)\end{array}$ \\
\hline 4 & Luka sayatan & $\begin{array}{l}\text { Flavanoid, } \\
\text { quercentin, } \\
\text { Alkaloid dan } \\
\text { tanin }\end{array}$ & & $\begin{array}{l}\text { Meningkatkan epitelisasi, } \\
\text { Menjaga dan meningkatkan } \\
\text { kadar kolagen dalam sel kulit } \\
\text { Memiliki aktivitas } \\
\text { pembersihan radikal bebas } \\
\text { Memiliki aktivitas } \\
\text { antimikroba } 22\end{array}$ & $\begin{array}{l}\text { Kumar, } \\
\text { Rajkiran } \\
\text { dan } \\
\text { Patnaik, } \\
\text { (2017) }\end{array}$ \\
\hline
\end{tabular}




\section{Aktivitas Antidiabetik Ekstrak Akar Mimosa pudica $L$.}

Selain mempunyai aktivitas wound healing, ditemukan adanya aktivitas antidiabetik dan antioksidan pada ekstrak Mimosa pudica L. Tunna, et al. tahun 2015 melaporkan bahwa kandungan paling tinggi pada pada ekstrak Mimosa pudica $L$. berupa metanol $(\mathrm{MeOHi})$ dan turunan fraksi metanol sebagai inhibitor pada enzim $\alpha$ glukosidase dan enzim $\alpha$-amilase dengan uji daya hambat menggunakan analisis GC Q-TOF MS. Proses penghambatan enzim pencernaan $\alpha$-glukosidase dan $\alpha$ - amilase pada pankreas fungsinya untuk mencegah penyerapan glukosa dalam darah, sehingga kadar glukosa dalam darah tidak melonjak tinggi (Yao, et al., 2013). Sedangkan temuan lain dalam penelitian Tunna, et al. (2015) menunjukkan adanya aktifitas antioksidan pada senyawa flavanoid dan fenol, senyawa ini mampu membersihkan radikal bebas yang berlebihan, memutuskan rantai reaksi radikal bebas, mengikat ion logam, dan menghambat enzim aldolase reduktase sehingga mampu mengurangi onset, mencegah komplikasi dan prognosis penyakit diabetes mellitus. Peneliti telah melakukan pencarian literatur tentang potensi antidiabetik dari ekstrak akar Mimosa pudica $L$ tabel 2 menunjukkan aktivitas antidiabetik ekstrak Mimosa pudica L.

Tabel 2. aktivitas antidiabetik ekstrak akar Mimosa pudica $L$.

\begin{tabular}{|c|c|c|c|c|}
\hline No & Uji Analisis & $\begin{array}{c}\text { Kandungan } \\
\text { Senyawa } \\
\text { Ekstrak }\end{array}$ & Hasil & Referensi \\
\hline 1 & 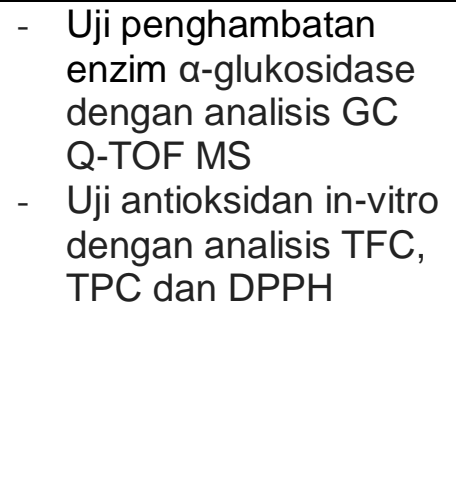 & $\begin{array}{l}\text { Metanol } \\
\left(\text { MeOH }_{i}\right) \\
\text { fraksi etil } \\
\text { asetat } \\
\text { (EtOAcf) } \\
\text { fenol dan } \\
\text { flavanoid }\end{array}$ & $\begin{array}{l}\text { Aktivitas menghambat } \\
\text { enzim a-glukosidase dan } \\
\text { enzim } \alpha \text {-amilase tiga kali } \\
\text { lipat lebih tinggi } \\
\text { dibandingkan dengan } \\
\text { acarbose. } \\
\text { - Aktifitas antioksidan pada } \\
\text { senyawa flavanoid dan } \\
\text { fenol, senyawa ini mampu } \\
\text { membersihkan radikal } \\
\text { bebas }^{19}\end{array}$ & $\begin{array}{l}\text { Tunna, et } \\
\text { al. (2015) }\end{array}$ \\
\hline 2 & $\begin{array}{l}\text { - Analisis spektral UV, } \\
\text { IR, NMR, MS }\end{array}$ & $\begin{array}{l}\text { Stigmasterol, } \\
\text { quercetin, } \\
\text { avicularin }\end{array}$ & $\begin{array}{l}\text { - Mempunyai aktifivas } \\
\text { inhibitor enzim pencernaan } \\
\alpha \text {-amilase dan } \alpha \text { - } \\
\text { glukosidase }^{23}\end{array}$ & $\begin{array}{c}\text { Tasnuva, } \\
\text { et al. } \\
\text { (2019) }\end{array}$ \\
\hline
\end{tabular}

\section{Efek Terapeutik Ozonasi}

Ozon dalah gas yang secara alami terdapat di atmosfir bumi berupa molekul triatomik yang merupakan bentuk alatropik dari oksigen yang sangat mudah larut. Ozon (O3) merupakan oksidan yang jauh lebih kuat dibandingkan dengan oksigen, sehingga dapat mengoksidasi banyak bahan yang inert terhadap oksigen pada kondisi normal (Elvis dan Ekta, 2011). Penggunaan ozon dalam dunia medis dengan melarutkan ozon dalam air (air ozonasi), minyak ozonasi, dan ozon dalam bentuk gas (Bocci, 2011).

Proses ozonasi menggunakan generator ozon dengan beberapa parameter yang dapat mempengaruhi kualitas ozonasi, parameter tersebut diantaranya kualitas generator ozon, kondisi ozonasi, waktu, konsentrasi ozon, aliran, suhu, agitasi campuran reaksi, jenis dan jumlah ekstrak, adanya air atau katalis lainnya (Ugazio et al., 2020). Penelitian lain menjelaskan tentang proses ozonasi air atau minyak nabati dilakukan dengan menggembungkan campuran gas $\left(\mathrm{O}_{2}-\mathrm{O}_{3}\right)$ dengan konsentrasi ozon $80-100 \mathrm{mcg} / \mathrm{ml}$ akan menghasilkan konsentrasi ozon akhir $25 \%$ yaitu $20-25 \mathrm{mcg} / \mathrm{ml}$. Ozonasi air tetap berkhasiat 1-2 hari, sedangkan ozonasi minyak tetap stabil selama 2 tahun jika di simpan dalam lemari es (Bocci, 2011). Studi lain menjelaskan proses ozonasi 
dengan teknologi plasma medis yaitu karakterisasi ozon menggunakan alat reaktor Dielectric Barrier Discharge Plasma (DBDP) dengan tegangan $25 \mathrm{kV}$, frekuensi maksimum $23 \mathrm{kHz}$ dengan proses ozonasi menghasilkan konsentrasi maksimum 20 $\mathrm{mg} / \mathrm{L}$ dan kapasitas ozon $48 \mathrm{~g} / \mathrm{jam}$ (Nur et al., 2017).

Beberapa penelitian menggunakan ozonasi sebagai agen topical therapy untuk membantu wound healing diantaranya ozonasi virgin coconut oil (VCO) (Yuniati et al., 2020) dan ozonasi minyak biji bunga matahari (Serio et al., 2017). Ozon diterapkan sebagai topical therapy yang memiliki sifat antibakteri, hemodinamik, antiinflamasi, mengaktifkan pembentukan jaringan granulasi, menginduksi pembentukan kolagen jaringan, mempercepat epitelisasi (pertumbuhan sel epidermis) serta meningkatkan aktivitas fagositik dan aktivasi fibroblas juga interaksi ozon dengan jaringan kulit dapat menyebabkan inaktivasi bakteri, virus dan jamur, serta merangsang produksi antioksidan (Song et al., 2018).

Terapi ozon juga mendukung pengobatan diabetes mellitus melalui penurunan kadar gula darah dengan mengurangi viskositas plasma darah, meningkatkan fluiditas membran eritrosit, merangsang aktivitas hemoglobin dan meningkatkan suplai oksigen ke jaringan (Kushmakov, et al., 2018).

\section{KESIMPULAN}

Ulkus diabetikum merupakan salah satu komplikasi mayor diabetes yang sering dialami oleh penderita diabetes mellitus. Ulkus diabetikum yang tidak ditangani dengan baik akan menyebabkan infeksi kronik sehingga meningkatkan kemungkinan amputasi. Penyembuhan luka ulkus diabetikum ada tiga fase, yaitu koagulasi-inflamasi, proliferasi dan renovasi sel. Sedangkan proses perawatan ulkus diabetikum terdiri dari tiga tahap, yaitu pembersihan (pencucian), debridemen, dan balutan luka.

\begin{tabular}{cccc}
\multicolumn{1}{c}{ Mimosa } & pudica & L. & mempunyai \\
kandungan & senyawa & kimia & yang \\
mempunyai & aktivitas & wound healing
\end{tabular}
diantaranya fenol, poliferol, flavanoid, quercentin, alkaloid dan tanin yang menghasilkan efek peningkatan koagulasi, proliferasi, epitelisasi, dan aktivitas antimikroba. Senyawa stigmasterol, quercetin, avicularin dan metanol mempunyai aktivitas antidiabetik dengan mekanisme seluler yaitu menghambat enzim $\alpha$-glukosidase dan enzim $\alpha$-amilase sehingga mampu menurunkan kadar glukosa dalam darah. Untuk meningkatkan proses wound healing dapat dilakukan melalui proses ozonasi sebagai antibakteri. Proses ozonasi menggunakan teknologi plasma medis berupa alat generator ozon yang mampu mengubah gas ozon menjadi cair dengan menggunakan paramaeter tertentu. Sehingga ekstrak akar Mimosa pudica $L$. dan metode ozonasi memiliki potensi untuk dikembangkan dalam menunjang penyembuhan ulkus diabetikum agar lebih efektif dan efisien sehingga dapat meningkatkan kualitas hidup penderita.

Penelitian dalam bentuk narrative review dapat dijadikan tentunya dapat dijadikan sebagai sumber literatur bagi penelitian selanjutnya. Perlu telaah lebih lanjut didukung dengan temuan penelitian lain yang masih memiliki tema tidak jauh dari inovasi ini

\section{UCAPAN TERIMA KASIH}

Terimakasih diucapkan kepada

Direktorat Pembelajaran dan Kemahasiswaan, Direktorat Jenderal Perguruan Tinggi Kementerian Pendidikan dan Kebudayaan atas pendanaan Program Kreativitas Mahasiswa-Penelitian tahun 2020 serta kepada Universitas Diponegoro dalam penyediaan berbagai fasilitas yang diperlukan.

\section{DAFTAR PUSTAKA}

Azam, S., Huda, A. F., Shams, K., Hasan, P. A. M., Mustafa, K. M., \& Hasan, M.M. et al. 2015. 'Anti-inflammatory and anti-oxidant study of ethanolic extract of Mimosa pudica', Journal of Young Pharmacists, 7(3), pp. 234240. doi: 10.5530/jyp.2015.3.14.

Bocci, V. 2011. 'Ozone: A new medical drug', Ozone: A New Medical Drug, pp.1-315. doi: 10.1007/978-90-4819234-2.

Bortoletto, M. S. S., de Andrade, S. M., Matsuo, T., Haddad, M. D. C. L., González, A. D., \& Silva, A. M. R. 
2014. 'Risk factors for foot ulcers - A cross sectional survey from a primary care setting in Brazil', Primary Care Diabetes, 8(1), pp. 71-76. doi: 10.1016/j.pcd.2013.04.003

Choi, J., Park, Y. G., Yun, M. S., \& Seol, J. W. 2018. 'Effect of herbal mixture composed of Alchemilla vulgaris and Mimosa on wound healing process', Biomedicine and Pharmacotherapy, 106(March), pp. 326-332. doi: 10.1016/j.biopha.2018.06.141.

Desalu, O. O., Salawu, F. K., Jimoh, A. K., Adekoya, A. O., Busari, O. A., \& Olokoba, A. B. 2011. 'Diabetic foot care: self reported knowledge and practice among patients attending three tertiary hospital in Nigeria.', Ghana medical journal, 45(2), pp. 6065. doi: 10.4314/gmj.v45i2.68930.

Elvis, A. M. and Ekta, J. S. 2011. 'Ozone therapy: A clinical review', Journal of Natural Science, Biology and Medicine, 2(1), pp. 66-70. doi: 10.4103/09769668.82319.

Jeffcoate, W. J., Vileikyte, L., Boyko, E. J., Armstrong, D. G., \& Boulton, A. J. 2018. 'Current challenges and opportunities in the prevention and management of diabetic foot ulcers', Diabetes Care, 41(4), pp. 645-652. doi: $10.2337 / \mathrm{dc} 17-1836$.

Karri, V. V. S. R., Kuppusamy, G., Talluri, S. V., Yamjala, K., Mannemala, S. S., \& Malayandi, R. 2016. 'Current and emerging therapies in the management of diabetic foot ulcers', Current Medical Research and Opinion, 32(3), pp. 519542.

doi: 10.1185/03007995.2015.1128888.

Kokane, D. D., More, R. Y., Kale, M. B., Nehete, M. N., Mehendale, P. C., \& Gadgoli, C. H. 2009. 'Evaluation of wound healing activity of root of Mimosa pudica', Journal of Ethnopharmacology, 124(2), pp. 311315. doi: 10.1016/j.jep.2009.04.038.

Kumar, R. S., Rajkiran, K. and Patnaik, S. K. 2017. 'Evaluation of Incisional Diabetic Wound Healing Activity of Ethanolic Leave Extract of Mimosa pudica L. in Rats', International Journal of Pharmacognosy and Phytochemical Research, 9(08), pp. 1143-1147. doi: 10.25258/phyto.v9i08.9623.
Kushmakov, R., Gandhi, J., Seyam, O., Jiang, W., Joshi, G., Smith, N. L., \& Khan,

S. A. 2018. 'Ozone therapy for diabetic foot', Medical Gas Research, 8(3), pp. 111-115. doi: 10.4103/20459912.241076.

Libon, C., Steward, N., Cousy, A., Rouquet, J., Issac-Visentin, C., Grondin, A., ... \& Nguyen, T. 2018. '1074 Mimosa pudica plant cell culture extracts (mimosine free) exhibit anti-inflammatory activities and inhibit the responses in vitro', Journal of Investigative Dermatology, 138(5), p. S182. doi: 10.1016/j.jid.2018.03.1087.

Nur, M., Susan, A. I., Muhlisin, Z., Arianto, F., Kinandana, A. W., Nurhasanah, I., ... \& Usman, A. (2017) 'Evaluation of novel integrated dielectric barrier discharge plasma as ozone generator', Bulletin of Chemical Reaction Engineering \&amp;amp; Catalysis, 12(1), pp. 24-31. doi: 10.9767/bcrec.12.1.605.24-31.

Sari, Y., Purnawan, I., Taufik, A., \& Sumeru, A. 2018. 'Quality of Life and Associated Factors in Indonesian Diabetic Patients with Foot Ulcers', Nurse Media Journal of Nursing, 8(1),p.13.doi:10.14710/nmjn.v8i1.1681 5.

Serio, F., Pizzolante, G., Cozzolino, G., D'Alba, M., Bagordo, F., De Giorgi, M., \& De Donno, A. 2017. 'A New Formulation Based on Ozonated Sunflower Seed Oil: In Vitro Antibacterial and Safety Evaluation', Ozone: Science and Engineering, 39(3), pp. 139-147. doi: 10.1080/01919512.2016.1272405.

Song, M., Zeng, Q., Xiang, Y., Gao, L., Huang, J., Huang, J., ... \& Lu, J. 2018. 'The antibacterial effect of topical ozone on the treatment of MRSA skin infection', Molecular Medicine Reports, 17(2), pp. 2449-2455. doi: 10.3892/mmr.2017.8148.

Tasnuva, S. T., Qamar, U. A., Ghafoor, K., Sahena, F., Jahurul, M. H. A., Rukshana, A. H., ... \& Ali, M. E. 2019. 'a-glucosidase inhibitors isolated from Mimosa pudica L.', Natural Product Research, pp. 1495-1499. doi: 10.1080/14786419.2017.1419224. 
Tunna, T. S., Zaidul, I. S. M., Ahmed, Q. U., Ghafoor, K., Al-Juhaimi, F. Y., Uddin, M. S., ... \& Ferdous, S. 2015. 'Analyses and profiling of extract and fractions of neglected weed Mimosa pudica Linn. traditionally used in Southeast Asia to treat diabetes', South African Journal of Botany, 99, pp. 144-152. doi: 10.1016/j.sajb.2015.02.016.

Ugazio, E., Tullio, V., Binello, A., Tagliapietra, S., \& Dosio, F. 2020. 'Ozonated oils as antimicrobial systems in topical applications. Their characterization, current applications, and advances in improved delivery techniques', Molecules, 25(2), pp. 124.doi: 10.3390/molecules25020334.

Volmer-Thole, M. and Lobmann, R. 2016. 'Neuropathy and diabetic foot syndrome', International Journal of Molecular Sciences, 17(6). doi: 10.3390/ijms17060917.

Younis, B. B., Shahid, A., Arshad, R., Khurshid, S., Ahmad, M., \& Yousaf, H.
2018. 'Frequency of foot ulcers in people with type 2 diabetes, presenting to specialist diabetes clinic at a Tertiary Care Hospital, Lahore, Pakistan', BMC Endocrine Disorders, 18(1), pp. 1-6. doi: 10.1186/s12902-018-0282-y.

Yuniati, R., Subchan, P., Riawan, W., Khrisna, M. B., Restiwijaya, M., Dyan, N. S., \& Nur, M. 2020. 'Topical ozonated virgin coconut oil improves wound healing and increases HSP90a, VEGF-A, EGF, bFGF and CD34 in diabetic ulcer mouse model of wound healing', F1000Research, 9(June), p. 580.

doi:

10.12688/f1000research.22525.1.

Zanardi, I., Borrelli, E., Valacchi, G., Travagli, V., \& Bocci, V. 2016. Ozone: a multifaceted molecule with unexpected therapeutic activity. Current Medicinal Chemistry, 23(4), 304-314. 